\title{
Multimicronutrient Slow-Release Fertilizer of Zinc, Iron, Manganese, and Copper
}

\author{
Siladitya Bandyopadhyay, Kunal Ghosh, and Chandrika Varadachari \\ Raman Centre for Applied and Interdisciplinary Sciences, 16 A Jheel Road, Calcutta 700 075, India \\ Correspondence should be addressed to Chandrika Varadachari; cv@rcais.res.in
}

Received 9 February 2014; Revised 5 June 2014; Accepted 12 June 2014; Published 1 July 2014

Academic Editor: Janez Levec

Copyright (C) 2014 Siladitya Bandyopadhyay et al. This is an open access article distributed under the Creative Commons Attribution License, which permits unrestricted use, distribution, and reproduction in any medium, provided the original work is properly cited.

\begin{abstract}
The process for the production of a slow-release micronutrient fertilizer is described. The compound contains zinc, iron, manganese, and copper as micronutrients and is produced by polymerizing a system containing phosphoric acid, zinc oxide, hematite, pyrolusite, copper sulfate, and magnesium oxide followed by neutralization of the polyphosphate chain with ammonium hydroxide. Changes in temperature, density, and viscosity of the reaction system during polymerization were studied. Reaction kinetics was studied at three different temperatures. Rate curves revealed a multistage process with essentially linear rates at each stage. Thus, each stage displayed zero order kinetics. The product was crystalline and revealed ordering of P-O-P chains. It had low solubility in water but high solubility in $0.33 \mathrm{M}$ citric acid and $0.005 \mathrm{M}$ DTPA. Three different field trials showed significant yield increments using the slow-release micronutrient fertilizer compared to the conventional micronutrients. Yield increments in rice were in the range of $10-55 \%$ over control (with no micronutrient) and up to $17 \%$ over the conventional micronutrient fertilizers. There were significant increases in total uptake of zinc, iron, and manganese in the grain. Slow-release fertilizers also produced significant yield increases in potato as well as significant increase in vitamin $\mathrm{C}$ content of the tuber.
\end{abstract}

\section{Introduction}

Micronutrients are essential components of proteins and enzymes and are vital for increasing crop yields as well as improving the nutritional quality of food. The bulk of micronutrients used all over the world today are water soluble salts that include mainly the sulfates or their chelated forms (EDTA, DTPA, etc.). Water solubility of these materials results in leaching and run-off, nutrient fixation by soil, high dosage requirements, and nonattractive cost economics. Slow-release fertilizers (which have low water solubility) are, therefore, considered as the solution to the problem. The focus of research on slow-release fertilizers has been on the macronutrients (NPK). Here slow-release functionality has been achieved by encapsulation of water soluble materials within a membrane or conversion to polymers of the urea aldehydes $[1,2]$. For micronutrients, the insoluble oxides and phosphate glasses are also used [3, 4]. A glassy phosphate produced by fusing oxides of micronutrients in phosphoric acid at $800^{\circ} \mathrm{C}$ has been described in a patent [5]. Volfkovich [6] studied long chain, highly condensed potassium metaphosphates containing small amounts of trace elements. Linear metaphosphates produced from ammonium and potassium dihydrogen phosphates, urea, and salts of micronutrient ions were described in a US patent [7]. These slow-release compositions are characterized by nutrient release mechanism that is based on either (i) diffusion through a membrane/coating or (ii) slow hydrolysis. Metaphosphates and glassy phosphates dissolve by slow hydrolysis to release nutrient into the soil. Nutrient release by diffusion or hydrolysis is dependent on soil parameters like water content, $\mathrm{pH}$, ionic content, temperature, and so forth. Therefore, the drawback of such release mechanisms is the possible mismatch between the rate at which the nutrient is released into the soil and the rate at which it is required by the crop. Insoluble compounds can be effective fertilizers only if rates of release of nutrient ions can match plant requirements throughout the growth period [8].

The slow-release fertilizer in this study has been developed with a different mechanism of nutrient release. Here, plant roots are able to "digest" certain insoluble compounds 
by ion-exchange with the root hairs or by extracellular organic acid secretions that extract nutrients by chelation. These compounds have low water solubility and high solubility in citrate and diethylene triamine penta acetic acid (DTPA) [8-12].

Whereas the earlier work mainly focused on individual cationic slow-release compounds [10-12], the present research was undertaken to develop a combined cationic micronutrient fertilizer that would incorporate all the major cationic micronutrients, namely, zinc, iron, manganese, and copper into a single compound. The advantage of such a product would be that a single fertilizer would provide all the cationic micronutrients and would thus prove beneficial to both the crop and the farmer.

Here, we report the process for production of slow-release multimicronutrient fertilizer of $\mathrm{Zn}, \mathrm{Fe}, \mathrm{Mn}$, and $\mathrm{Cu}$. Studies on polymerization kinetics, process parameters, changes in physical properties, and product characterization were done. The process was optimized on a small pilot plant. Finally, field trials were conducted with three different crops. Results indicate that the compound is a very promising fertilizer.

\section{Materials and Methods}

2.1. Synthesis and Process Studies. Based on the average levels of $\mathrm{Zn}, \mathrm{Fe}, \mathrm{Mn}$, and $\mathrm{Cu}$ in plants [3], the weight ratio of $\mathrm{Zn}: \mathrm{Fe}: \mathrm{Mn}: \mathrm{Cu}$ was chosen as $3: 1: 0.5: 0.25$. From preliminary trials, the proportions of $\mathrm{P}$ and $\mathrm{Mg}$ were also optimized so that the optimal weight ratio in the reaction system was $3: 1: 0.5: 0.25: 0.125: 8$ for $\mathrm{Zn}: \mathrm{Fe}: \mathrm{Mn}: \mathrm{Cu}: \mathrm{Mg}: \mathrm{P}$.

Synthesis was done with commercial grade chemicals, namely, hematite, pyrolusite, zinc ash, copper sulfate, roasted magnesite, and phosphoric acid. All raw materials were analyzed prior to synthesis using analytical grade reagents. Iron in hematite was determined spectrophotometrically as the o-phenanthroline complex [13]. Manganese in pyrolusite was determined as the permanganate color after oxidation with $\mathrm{KIO}_{3}$ [13]. Zinc ash, copper sulfate, and magnesite were analyzed for their $\mathrm{Zn}^{2+} / \mathrm{Cu}^{2+} / \mathrm{Mg}^{2+}$ contents by AAS. Commercial $\mathrm{H}_{3} \mathrm{PO}_{4}$ was analyzed for $\mathrm{P}$ content as the blue phosphomolybdate [14] after fusion of polyphosphate with $\mathrm{NaOH}$ [10]. Hematite contained $46.28 \%$ Fe, pyrolusite $49.31 \%$ $\mathrm{Mn}$, zinc ash $76.70 \% \mathrm{Zn}$, copper sulfate $22.24 \% \mathrm{Cu}$, magnesite $41.72 \% \mathrm{Mg}$, and phosphoric acid 25.56\% P.

Fertilizer production was done in a pilot plant which was a $20 \mathrm{~L}$ acid-proof brick lined reactor vessel. $10 \mathrm{~kg}$ of phosphoric acid was taken in the vessel and $1.25 \mathrm{~kg}$ zinc ash was added to it. This was followed by $0.69 \mathrm{~kg}, 0.324 \mathrm{~kg}$, $0.357 \mathrm{~kg}$, and $0.096 \mathrm{~kg}$, respectively, of hematite, pyrolusite, copper sulfate, and magnesite. The mole ratios of the cations added with respect to moles of phosphorus are thus $\mathrm{Zn} / \mathrm{P}=$ $0.18, \mathrm{Fe} / \mathrm{P}=0.07, \mathrm{Mn} / \mathrm{P}=0.03, \mathrm{Cu} / \mathrm{P}=0.01$, and $\mathrm{Mg} / \mathrm{P}=0.02$. The mole ratio of all cations added to moles of phosphorus is $0.32: 1$. The reactants were heated with agitation at $200^{\circ} \mathrm{C}$ for $230 \mathrm{~min}$. The liquid was poured into a mixer and cooled to room temperature. After cooling, the liquid formed viscous liquid and not a glass since fusion temperatures were not attained during polymerization. This liquid was then neutralized with $9.5 \mathrm{~L}$ of ammonia to $\mathrm{pH}$
5.6. Due to exothermicity of the reaction, temperature during neutralization was around $90^{\circ} \mathrm{C}$. Finally, the neutralized suspension was dried in an oven at $70-80^{\circ} \mathrm{C}$, ground, and sieved through 80 mesh. This product obtained from the pilot plant was used for chemical and field studies.

Changes in temperature, density, and viscosity in the course of polymerization reaction were recorded. Temperature was recorded in situ. Density was recorded in a density bottle. Viscosity was recorded by Redwood viscometer with a high temperature bath set at the temperature of the reaction liquid.

2.2. Reaction Kinetics. Since the reaction for formation of polyphosphates is a polycondensation reaction, kinetics is most conveniently studied by recording weight loss (water loss) of the system [15]. Weight loss kinetics was studied in glass beakers using 1/10th of the reactants mentioned in the synthesis experiment. The process here was similar to that described in Section 1 except that it was done in borosilicate beakers using accurately weighed reactants. Initial weight of beaker was recorded and weights were also recorded after addition of acid. Subsequently, the process described above was followed except that heating was done in a muffle furnace with temperature controls of $0.1^{\circ} \mathrm{C}$. At specific time intervals, weight of the beaker was recorded and weight loss was estimated. Weight loss was recorded at $175^{\circ}, 200^{\circ}$, and $225^{\circ} \mathrm{C}$ at periodic intervals up to $240 \mathrm{~min}$.

2.3. Characterization and Testing. Chemical analysis of the fertilizer for $\mathrm{P}$ was done by fusion of $0.1 \mathrm{~g}$ with $1.5 \mathrm{~g}$ of $\mathrm{NaOH}$ beads and extraction in $0.2 \mathrm{~N} \mathrm{HCl}$. P was determined spectrophotometrically as described above. Cations were determined after digestion with concentrated $\mathrm{H}_{2} \mathrm{SO}_{4}-\mathrm{H}_{2} \mathrm{O}_{2}$ and the solution analyzed for $\mathrm{Zn}, \mathrm{Fe}, \mathrm{Mn}, \mathrm{Cu}$ and $\mathrm{Mg}$ as described earlier. $\mathrm{NH}_{4}{ }^{+}$-content was determined by Kjeldahl method [14].

Solubility of the fertilizer in water was determined by adding $50 \mathrm{~mL}$ water to $0.1 \mathrm{~g}$ fertilizer, agitating for $60 \mathrm{~min}$ followed by filtration. The solution was analyzed for $\mathrm{Zn}, \mathrm{Fe}$, $\mathrm{Mn}, \mathrm{Cu}$, and P. Solubility in $0.33 \mathrm{M}$ citric acid and $0.005 \mathrm{M}$ DTPA was determined by a similar procedure except that water was replaced by $0.33 \mathrm{M}$ citric acid and $0.005 \mathrm{M}$ DTPA.

Infrared (IR) spectra of the powdered sample were recorded on a Perkin Elmer Fourier transform infrared (FTIR) RX1 instrument with the scan range of 4500$450 \mathrm{~cm}^{-1}$ (resolution $\pm 5 \mathrm{~cm}^{-1}$ ) using $\mathrm{KBr}$ pellets. X-ray diffraction (XRD) was recorded on a Philips PW 1140 X-ray diffractometer using $\mathrm{Ni}$-filtered $\mathrm{CuK}_{\alpha}$ radiation at a scanning speed of $2^{\circ} 2 \theta / \mathrm{min}$.

Field tests were conducted with three crops at two different locations. These were at (i) Baruipur (South-24 Parganas), West Bengal, India, (fine, mixed, hyperthermic aeric endoaquept; new alluvium), $\mathrm{pH} 5.73, \mathrm{EC}_{e} 2.90 \mathrm{dS} / \mathrm{m}$ and organic carbon $9.05 \mathrm{~g} / \mathrm{kg}$ and (ii) Nalikul (Hooghly), West Bengal, India, (fine, mixed, hyperthermic typic haplustept; old alluvium), $\mathrm{pH}$ 6.17, $\mathrm{EC}_{e} 1.49 \mathrm{dS} / \mathrm{m}$ and organic carbon $6.91 \mathrm{~g} / \mathrm{kg}$. Randomized block design (RBD) with 6 replicates was used for the field trials with $9 \mathrm{~m}^{2}$ area per microplot. The 
TABLE 1: Solubility, IR, and XRD characteristics of the slow-release fertilizer.

\begin{tabular}{|c|c|c|c|c|c|c|c|}
\hline \multirow{2}{*}{$\begin{array}{l}\text { Chemical } \\
\text { component }\end{array}$} & \multicolumn{3}{|c|}{$\%$ of total solubilized in } & \multicolumn{2}{|c|}{ IR absorption in wavenumber $\left(\mathrm{cm}^{-1}\right)$} & \multicolumn{2}{|c|}{ XRD peaks } \\
\hline & Water & $\begin{array}{c}0.33 \mathrm{M} \text { citric } \\
\text { acid }\end{array}$ & $\begin{array}{c}0.005 \mathrm{M} \\
\text { DTPA }\end{array}$ & $\begin{array}{l}\text { Wavenumber } \\
\qquad\left(\mathrm{cm}^{-1}\right)\end{array}$ & Absorbance & $\begin{array}{c}\text { Basal spacing } d_{001} \\
(\AA)\end{array}$ & Intensity $(I)$ \\
\hline $\mathrm{Zn}$ & ND & 93.7 & 83.9 & 447.7 & 42 & 6.29 & 16 \\
\hline $\mathrm{Fe}$ & ND & 93.2 & 918 & 544.3 & 40 & 5.33 & 56 \\
\hline & Nos & 30.2 & 11.0 & 1073.1 & 36 & 4.67 & 15 \\
\hline $\mathrm{Mn}$ & ND & 90.9 & 80.1 & 1280.6 & 40 & 4.41 & 15 \\
\hline $\mathrm{Cu}$ & 1.8 & 96.8 & 91.3 & 1450.7 & 38 & 3.76 & 50 \\
\hline \multirow[t]{7}{*}{$\mathrm{P}$} & 8.4 & & & 1656.0 & 41 & 3.08 & 100 \\
\hline & & & & 2375.1 & 41 & 2.66 & 16 \\
\hline & & & & 3238.4 & 35 & 2.62 & 10 \\
\hline & & & & & & 2.38 & 13 \\
\hline & & & & & & 2.34 & 8 \\
\hline & & & & & & 2.24 & 8 \\
\hline & & & & & & 1.60 & 26 \\
\hline
\end{tabular}

treatments include (i) a control (where only NPK fertilizers but no micronutrients were added), (ii) three different levels of slow-release micronutrient fertilizer, and (iii) the same three levels of micronutrients as micronutrient sulfates. All plots received equal applications of $\mathrm{N}, \mathrm{P}, \mathrm{K}$, and $\mathrm{Mg}$ by calculated additions of urea, diammonium phosphate (DAP), $\mathrm{KCl}$, and $\mathrm{MgSO}_{4}$. Test crops were rice (Jaya/Niranjan varieties) and potato (Jyoti variety). Micronutrient contents of rice grain straw and potato tuber were analyzed for all treatments and replicates. Grains/tubers were oven dried, powdered in a grinder, digested in triacid mixture [14], and analyzed for micronutrients by AAS. Potato tuber was also analyzed for vitamin $C$ by extracting fresh sliced tuber with $4 \%$ oxalic acid and triturating the extract with 2,6-dichloro indophenol dye [16]. All results were statistically analyzed.

\section{Results and Discussion}

3.1. Process Parameters. Temperature optimization studies showed that the reaction was $30.3 \%$ faster at $200^{\circ} \mathrm{C}$ than at $185^{\circ} \mathrm{C}$ and $19.6 \%$ faster at $225^{\circ} \mathrm{C}$ than at $200^{\circ} \mathrm{C}$. Temperature in the range of $175-185^{\circ} \mathrm{C}$ required very long periods for completing polymerization. Again, higher temperature $\left(225^{\circ} \mathrm{C}\right)$ consumed more energy and was not much faster compared to $200^{\circ} \mathrm{C}$. Thus, temperature of $200^{\circ} \mathrm{C}$ appeared to be the optimum.

Changes in temperature, density, and viscosity in course of polymerization of $\mathrm{Zn}-\mathrm{Fe}-\mathrm{Mn}-\mathrm{Cu}-\mathrm{Mg}$ polyphosphate systems are shown in Figures 1-3. Liquid temperature increased with time due to increase in boiling point of the phosphate with polymerization. Temperature increment followed a first order rate (Figure 1). Rate of temperature rise increases with time as structural water reduces and fewer $\mathrm{P}-\mathrm{OH}$ groups are available for polymerization.

Density increases almost linearly with temperature, reaching $2.13 \mathrm{~g} / \mathrm{cc}$ after 280 minutes of heating (Figure 2). Formation of longer polymer chains and cross-linking of the $\mathrm{P}-\mathrm{O}-\mathrm{P}$ chains would account for such density increments. Viscosity changes showed an initial small reduction which may be attributed to the effect of increasing temperature

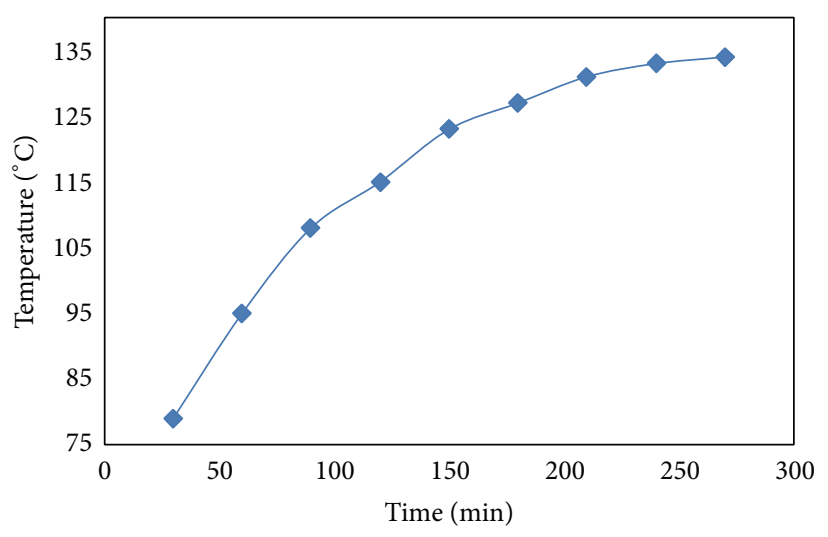

FIgURE 1: Temperature change during the polymerization reaction.

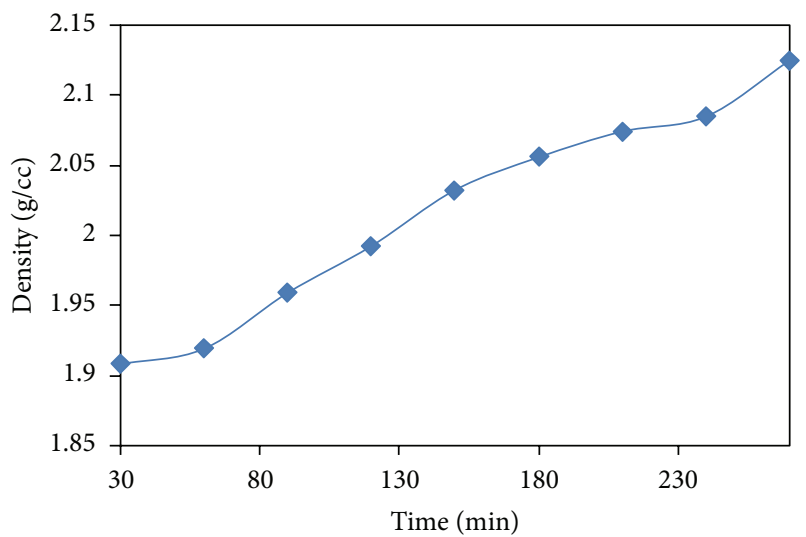

FIGURE 2: Density change during the polymerization reaction.

(Figure 3). Viscosity remained nearly constant till about $120^{\circ} \mathrm{C}$ and then increased very rapidly. Increased viscosity corresponds to the beginning of polymerization. Viscosity of the system was 101 centipoise at $134^{\circ} \mathrm{C}$.

3.2. Reaction Kinetics. Kinetics of condensation of $\mathrm{Zn}-\mathrm{Fe}-$ $\mathrm{Mn}-\mathrm{Cu}$ polyphosphates is shown in Figure 4. The rate curves 


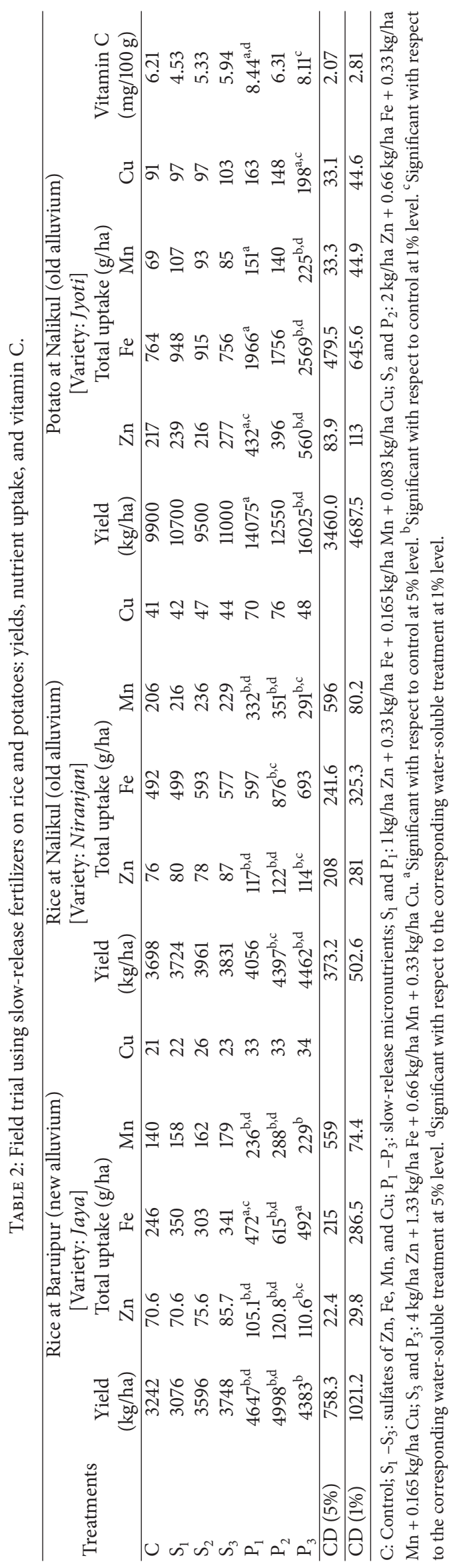




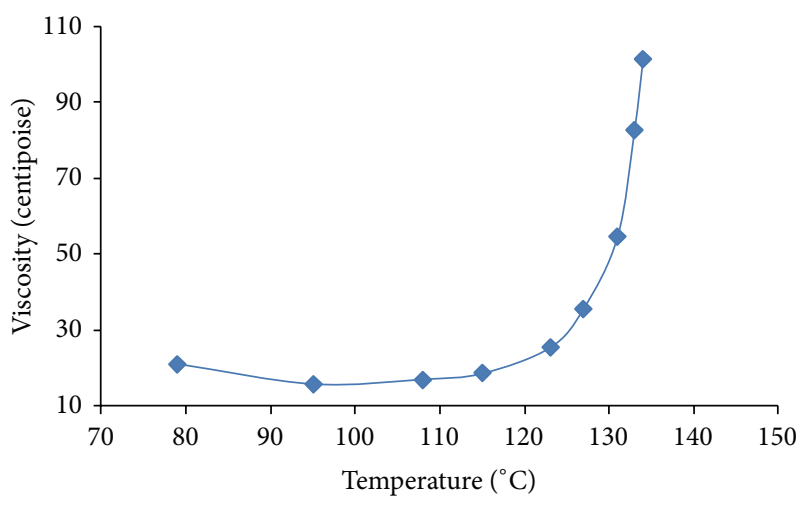

FIGURE 3: Viscosity change during the polymerization reaction.

did not fit into a first, second, or third order kinetic equation. As with polyphosphates studied earlier [10-12], polymerization exhibited several stages with each stage being nearly linear. Initial rapid rates have been attributed to the removal of one mole of $\mathrm{H}_{2} \mathrm{O}$ from every two molecules of dihydrogen phosphate with the formation of polyphosphates of varying chain length [15]. With the reduction in concentration of P$\mathrm{OH}$ groups available for polymerization, the reaction slowed down. The absence of a plateau indicates that polymerization was incomplete at the temperatures and time periods studied. Thus, long chain metaphosphates would not have been formed.

At the start of reaction, metal oxides would react with phosphoric acid to produce the respective dihydrogen phosphates. Subsequent (partial) polymerization to the polyphosphates may be represented as

$$
\begin{gathered}
n \mathrm{Zn}\left(\mathrm{H}_{2} \mathrm{PO}_{4}\right)_{2} \longrightarrow \mathrm{Zn}_{n} \mathrm{H}_{(2 n+2)} \mathrm{P}_{2 n} \mathrm{O}_{(7 n+1)}+(n-1) \mathrm{H}_{2} \mathrm{O} \\
n \mathrm{Fe}\left(\mathrm{H}_{2} \mathrm{PO}_{4}\right)_{3} \longrightarrow \mathrm{Fe}_{n} \mathrm{H}_{(4 n+2)} \mathrm{P}_{3 n} \mathrm{O}_{(11 n+1)}+(n-1) \mathrm{H}_{2} \mathrm{O} \\
n \mathrm{Mn}\left(\mathrm{H}_{2} \mathrm{PO}_{4}\right)_{4} \longrightarrow \mathrm{Mn}_{n} \mathrm{H}_{(6 n+2)} \mathrm{P}_{4 n} \mathrm{O}_{(15 n+1)}+(n-1) \mathrm{H}_{2} \mathrm{O} \\
n \mathrm{Cu}\left(\mathrm{H}_{2} \mathrm{PO}_{4}\right)_{2} \longrightarrow \mathrm{Cu}_{n} \mathrm{H}_{(2 n+2)} \mathrm{P}_{2 n} \mathrm{O}_{(7 n+1)}+(n-1) \mathrm{H}_{2} \mathrm{O} \\
n \mathrm{Mg}\left(\mathrm{H}_{2} \mathrm{PO}_{4}\right)_{2} \longrightarrow \mathrm{Mg}_{n} \mathrm{H}_{(2 n+2)} \mathrm{P}_{2 n} \mathrm{O}_{(7 n+1)}+(n-1) \mathrm{H}_{2} \mathrm{O}
\end{gathered}
$$

Cations including $\mathrm{Mg}^{2+}$ could form part of the chain and also cross-link different chains and thereby stabilize the structure.

3.3. Characterization and Testing. The compound is a zinc iron manganese copper magnesium ammonium polyphosphate with a composition of $9.85 \% \mathrm{ZnO}, 3.70 \% \mathrm{Fe}_{2} \mathrm{O}_{3}, 2.03 \%$ $\mathrm{MnO}_{2}, 0.73 \% \mathrm{CuO}, 0.49 \% \mathrm{MgO}, 13.5 \% \mathrm{NH}_{4}{ }^{+}, 47.11 \% \mathrm{P}_{2} \mathrm{O}_{5}$, and $3.10 \% \mathrm{H}_{2} \mathrm{O}$. The mole ratio of the cations to phosphorus is thus $\mathrm{Zn} / \mathrm{P}=0.19, \mathrm{Fe} / \mathrm{P}=0.07, \mathrm{Mn} / \mathrm{P}=0.03, \mathrm{Cu} / \mathrm{P}=0.01$, and $\mathrm{Mg} / \mathrm{P}=0.02$. A minor deviation from the added mole ratios is possibly due to losses during pilot production such as spillage and the fact that weighing at this level has lower accuracy than lab scale weighing. The final product is a freeflowing, pinkish powder. The extract with water showed that $1.8 \%$ of total $\mathrm{Cu}$ and $8.4 \%$ of total $\mathrm{P}$ were soluble but other

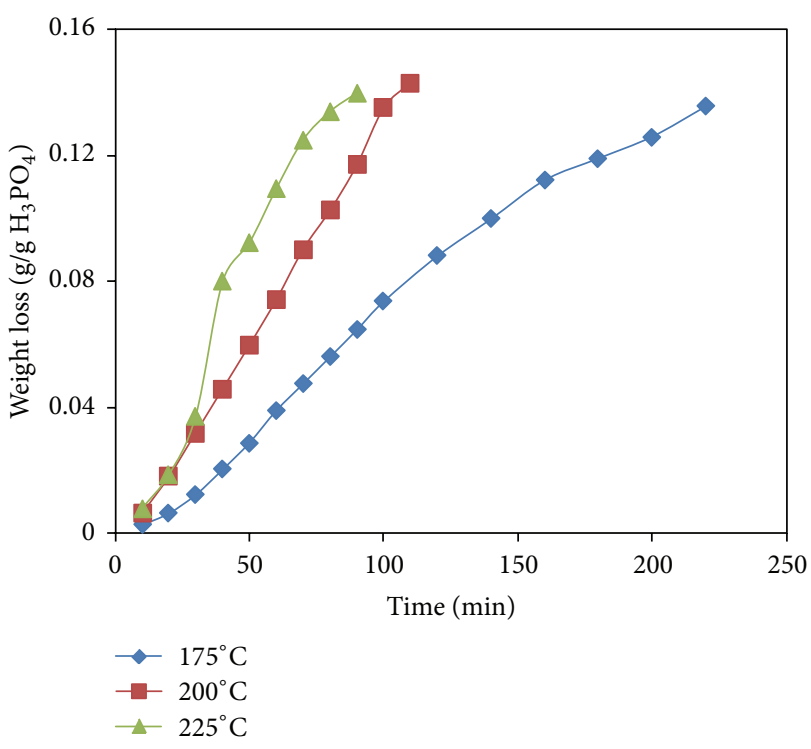

FIgURE 4: Kinetics of polymerization at 175,200 and $225^{\circ} \mathrm{C}$.

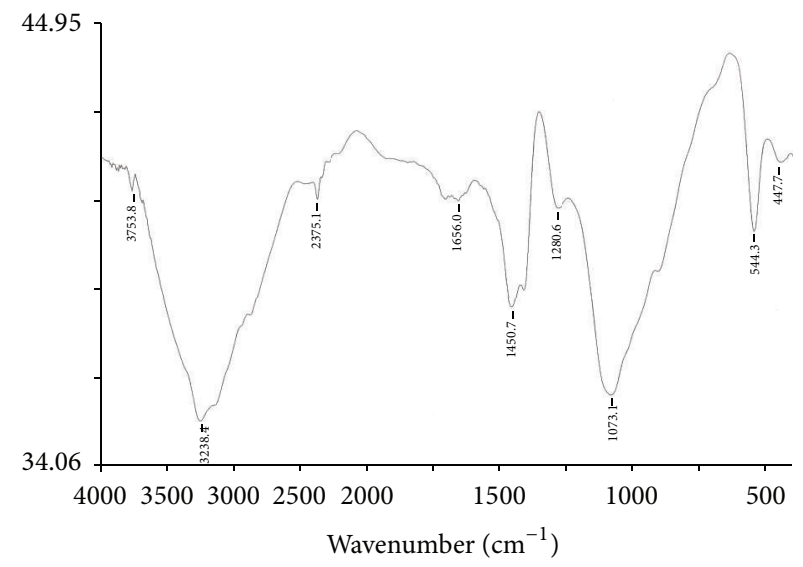

FIGURE 5: IR spectra of zinc-iron-manganese-copper fertilizer.

cations were not detectable. Solubility in $0.33 \mathrm{M}$ citric acid was $>90 \%$ for all micronutrients and solubilities in $0.005 \mathrm{M}$ DTPA were slightly lower, namely, 80-90\% (Table 1).

Infrared (IR) spectrum of the compound (Figure 5, Table 1) showed absorption characteristic of polyphosphates. Strong absorption around $1100-1050 \mathrm{~cm}^{-1}$ is due to $\mathrm{P}-\mathrm{O}$ ionic stretching [17] and that between $550-540 \mathrm{~cm}^{-1}$ is due to P$\mathrm{O}$ stretching in the deformation mode. Strong absorption at around $3200-3100 \mathrm{~cm}^{-1}$ is attributed to $\mathrm{O}-\mathrm{H}$ stretching [17]. An increase in length of the P-O-P chain results in a shift of the $\mathrm{P}-\mathrm{O}$ ionic stretching at around $1000 \mathrm{~cm}^{-1}$ to longer wavenumbers [17]. Absorption bands of the sample in the region of $1073 \mathrm{~cm}^{-1}$, therefore, suggest the presence of medium chain polyphosphates. Moderately strong absorption at $1450 \mathrm{~cm}^{-1}$ could be due to the presence of $\mathrm{NH}_{4}{ }^{+}$ion in the compounds [17].

$\mathrm{X}$-ray diffraction (XRD) characteristics of $\mathrm{Zn}-\mathrm{Fe}-\mathrm{Mn}-\mathrm{Cu}-$ $\mathrm{Mg}$ polyphosphate are shown in Figure 6 and Table 1. Sharp 


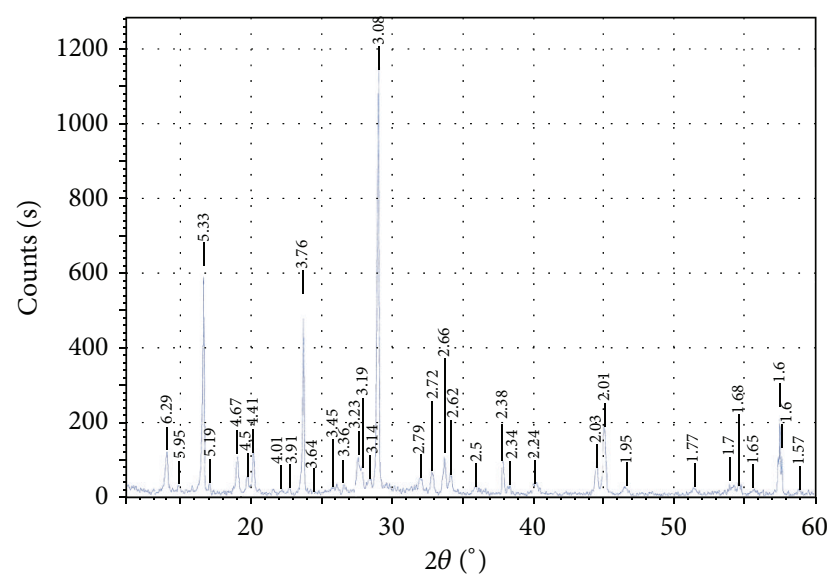

FIGURE 6: XRD of zinc-iron-manganese-copper fertilizer.

bands indicate a well-crystallized structure. The strongest line at around $3.08 \AA$ may be attributed to the polyphosphate backbone since it has been persistently observed in other polyphosphates of similar nature $[10-12,18]$. Strong lines were also found at around $5.33 \AA$ due to the presence of ammonium phosphates and at around $3.76 \AA$ attributable to ammonium phosphates and ammonium-iron pyrophosphate [19]. Reflections have also been found at around $2.62 \AA$ and $2.24 \AA$ indicating the presence of $\mathrm{Mn}_{2} \mathrm{P}_{2} \mathrm{O}_{7}$ [19].

Results of field trials showed that yield of rice grains increased by $35-55 \%$ in slow-release fertilizer treated plots over the control in the experiment at Baruipur (new alluvium). Yields were also higher compared to the micronutrient sulfate treated plots by $51.1,38.9$, and $17 \%$ for treatments $\mathrm{P}_{1}$, $\mathrm{P}_{2}$, and $\mathrm{P}_{3}$, respectively, over the corresponding micronutrient sulfate treatments, $S_{1}, S_{2}$, and $S_{3}$. Total uptake of $\mathrm{Zn}, \mathrm{Fe}$, and $\mathrm{Mn}$ in the polyphosphate treated plots was significantly higher than control and micronutrient sulfate treatments at $1 \%$ level (Table 2). Uptake of $\mathrm{Cu}$ increased in all polyphosphate treatments but was not significant at $5 \%$ level. Significant yield increments with rice were also observed from the trials at Nalikul (old alluvium). Yield of grain increased by $10-21 \%$ in the slow-release treatments over the control and by $9-16 \%$ over the corresponding micronutrient sulfate treatments. Total uptake of $\mathrm{Zn}, \mathrm{Fe}$, and $\mathrm{Mn}$ in the slow-release fertilizer treated plots was significantly higher than control and micronutrient sulfate treatments although increments of $\mathrm{Cu}$ did not appear as statistically significant (Table 2). Slow-release fertilizer also produced yield increments in potato at levels $\mathrm{P}_{1}$ and $\mathrm{P}_{2}$. Interestingly, Vitamin $\mathrm{C}$ contents in potato tubers treated with the slowrelease fertilizer increased significantly by over $30 \%$ over the control. Micronutrient sulfates did not produce any increase in vitamin $\mathrm{C}$ levels. Total uptake of micronutrients $\mathrm{Zn}, \mathrm{Fe}$, $\mathrm{Mn}$, and $\mathrm{Cu}$ in the tubers also increased significantly in slowrelease fertilizer treatments (Table 2). It may be inferred from the field trials that the slow-release fertilizer is an effective source of micronutrients and superior to the conventional micronutrient sulfates that are generally in use.
In conclusion, the slow-release micronutrient fertilizer reported here is a crystalline polyphosphate of $\mathrm{Zn}-\mathrm{Fe}-\mathrm{Mn}$ $\mathrm{Cu}-\mathrm{Mg}-\mathrm{NH}_{4}$. It had low water solubility but was almost completely soluble in organic acids, namely, $0.33 \mathrm{M}$ citric acid and $0.005 \mathrm{M}$ DTPA which suggests good plant availability. Reaction kinetics showed complex pattern with several stages, each being nearly linear. Features suggested a condensation reaction of $\mathrm{P}-\mathrm{OH}$ groups with zero order rates that changed with degree of polymerization. P-O-P linkages were evidenced by IR spectra. XRD showed long range order of polyphosphate groups. All three field tests resulted in significantly higher yields in the slow-release fertilizer plots over the control plots as well as over the conventional micronutrients. Plant uptake of micronutrients was also higher with the slow-release fertilizer. Potato tubers had significantly increased levels of vitamin C.

\section{Conflict of Interests}

The authors declare that there is no conflict of interests regarding the publication of this paper.

\section{Acknowledgments}

The authors thank Professor P Ray, Department of Chemical Engineering, Calcutta University, for his suggestions. They also thank NBSS \& LUP, ICAR, Nagpur, for XRD scans and Professor A Patra, Department of Chemistry, Calcutta University, for the IR analysis.

\section{References}

[1] A. Shaviv, "Advances in controlled-release fertilizers," Advances in Agronomy, vol. 71, pp. 1-49, 2001.

[2] F. N. Wilson, Slow Release-True or False? A Case of Control, The Fertilizer Society of London, London, UK, 1988.

[3] J. J. Mortvedt, F. R. Cox, L. M. Shuman, and R. M. Welch, Micronutrients in Agriculture, Soil Science Society of America, Madison, Wis, USA, 1991.

[4] G. J. Roberts, "FeO- $\mathrm{K}_{2} \mathrm{O}-\mathrm{P}_{2} \mathrm{O}_{5}$ glasses as source of micronutrient in soil," American Ceramic Society Bulletin, vol. 54, pp. 10691071, 1975.

[5] Krems-Chemie, "Complete fertilizers containing trace elements," Austrian Patent 326,160, 1975.

[6] S. I. Volfkovich, "Polymeric fertilizers," Journal of Applied Chemistry of the USSR, vol. 45, pp. 2479-2487, 1972.

[7] J. W. Lyons, G. A. Rauh Jr., and S. A. Vandersall, "Mixed cation polyphosphates," US Patent no. 3574591, 1971.

[8] S. Bandyopadhyay, I. Bhattacharya, K. Ghosh, and C. Varadachari, "New slow-releasing molybdenum fertilizer," Journal of Agricultural and Food Chemistry, vol. 56, no. 4, pp. 1343-1349, 2008.

[9] C. Varadachari, "Process for the manufacture of bio-release fertilizers of zinc-iron-manganese, iron-manganese-copper and zinc-iron-manganese-copper," US Patent 8,216,337, 2012.

[10] S. K. Ray, C. Varadachari, and K. Ghosh, "Novel slow-releasing micronutrient fertilizers. 1. Zinc compounds," Industrial and Engineering Chemistry Research, vol. 32, no. 6, pp. 1218-1227, 1993. 
[11] S. K. Ray, C. Varadachari, and K. Ghosh, "Novel slow-releasing micronutrient fertilizers. 2. Copper compounds," Journal of Agricultural \& Food Chemistry, vol. 45, no. 4, pp. 1447-1453, 1997.

[12] P. K. Chandra, C. Varadachari, and K. Ghosh, "A new slowreleasing iron fertilizer," Chemical Engineering Journal, vol. 155, no. 1-2, pp. 451-456, 2009.

[13] J. A. Maxwell, Rock and Mineral Analysis, Interscience, New York, NY, USA, 1968.

[14] M. L. Jackson, Soil Chemical Analysis, Prentice Hall, New Delhi, India, 1973.

[15] C. Varadachari, "An investigation on the reaction of phosphoric acid with mica at elevated temperatures," Industrial \& Engineering Chemistry Research, vol. 31, no. 1, pp. 357-364, 1992.

[16] M. B. Davies, J. Austin, and D. A. Partridge, Vitamin C: Its Chemistry and Biochemistry, Royal Society of Chemistry, London, UK, 1991.

[17] D. E. C. Corbridge, E. J. Lowe, and D. E. C. Corbridge, "Infrared spectra of some inorganic phosphorus Compounds," Journal of Chemical Society, pp. 493-502, 1954.

[18] I. Bhattacharya, S. Bandyopadhyay, C. Varadachari, and K. Ghosh, "Development of a novel slow-releasing iron-manganese fertilizer compound," Industrial \& Engineering Chemistry Research, vol. 46, no. 9, pp. 2870-2876, 2007.

[19] JCPDS, Power Diffraction File, International Centre for Diffraction Data, Pennsylvania, Pa, USA, 1984. 

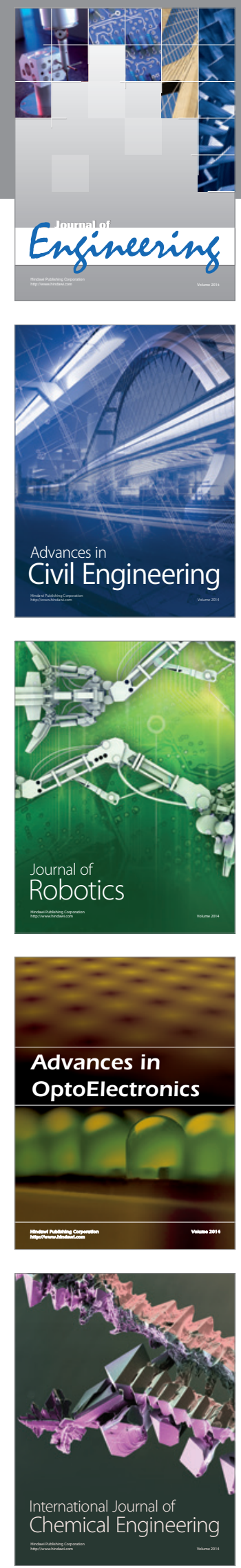

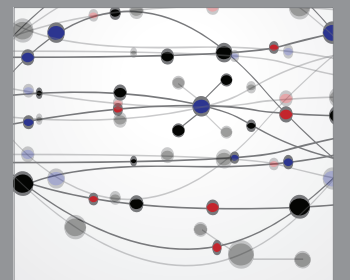

The Scientific World Journal
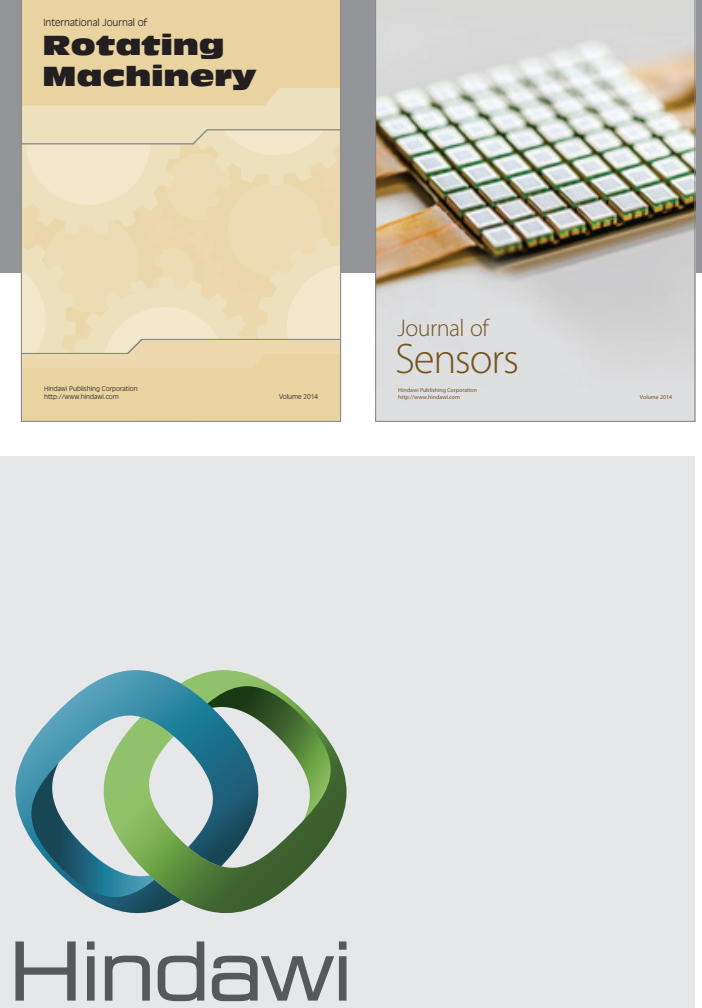

Submit your manuscripts at http://www.hindawi.com
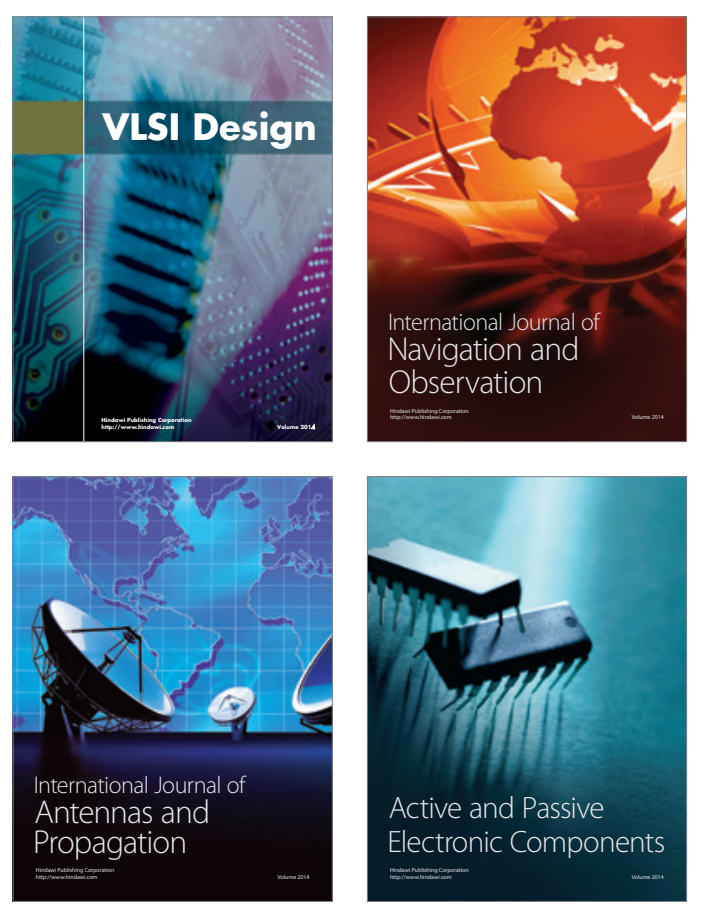
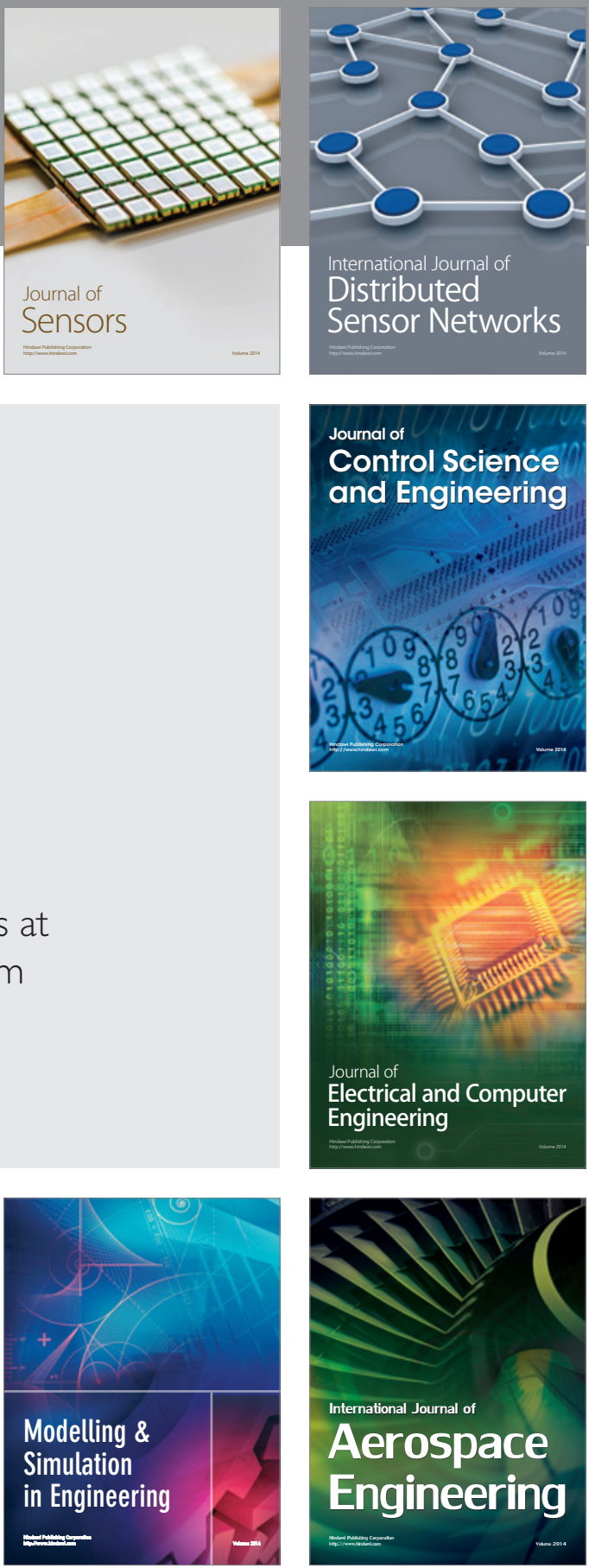

Journal of

Control Science

and Engineering
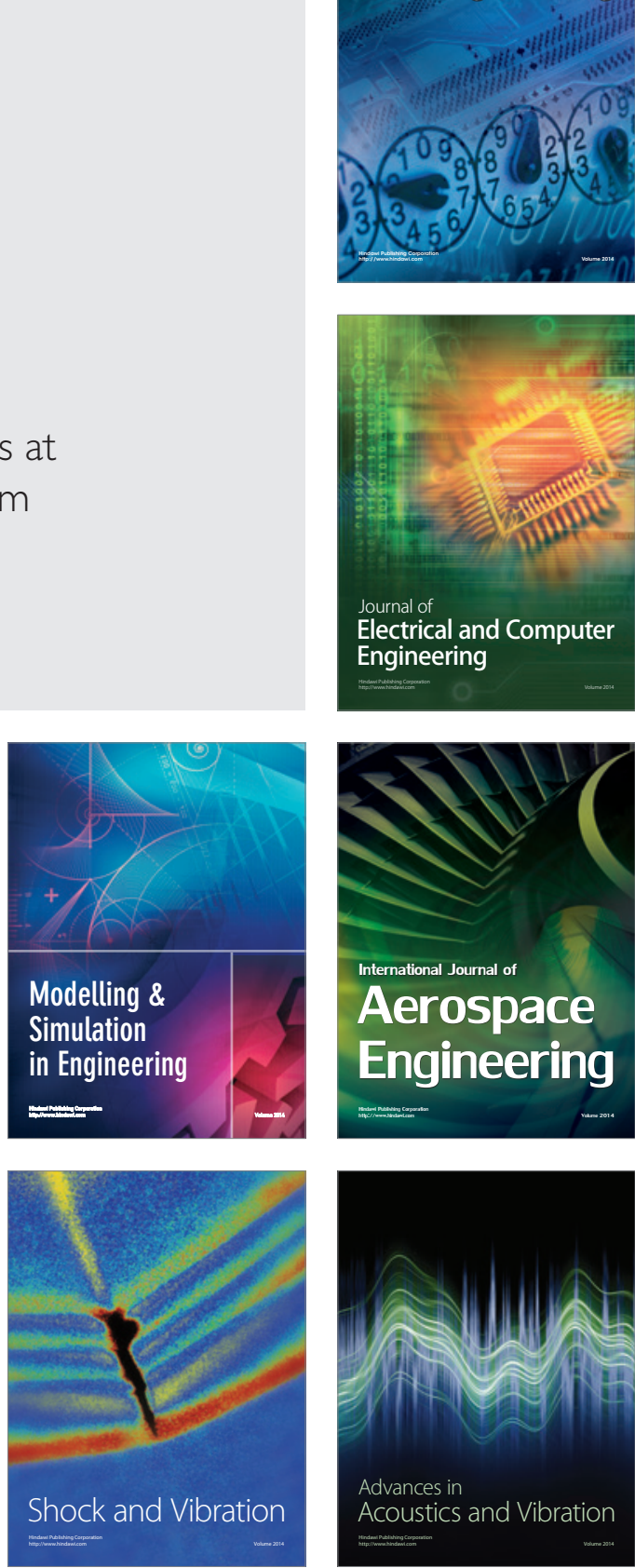